\title{
Thermal shock resistance of core reinforced all-ceramic crown systems
}

\author{
Gary P. Mora and William J. O'Brien* \\ Department of Biologic and Materials Sciences, School of Dentistry, The University of Michigan, Ann Arbor, \\ Michigan 48109
}

The coefficient of thermal expansion of core and veneer porcelains for all ceramic crowns must be compatible to prevent formation of stresses during the firing cycles. The purpose of this study was to use a thermal shock test to evaluate the crazing resistance of six all-ceramic crown systems. The systems tested were: Vita In-Ceram ${ }^{\circledast}$, Vita Hi-Ceram ${ }^{\circledR}$, Dicor $^{\mathrm{TM}}$ veneered with Vitadur $^{\circledR} \mathrm{N}$, magnesia core veneered with Ceramco ${ }^{\circledR}$ II, magnesia core veneered with Silhouette ${ }^{\mathrm{TM}}$, and magnesia core veneered with Vita $\mathrm{VMK}^{\circledR}$ 68. A maxillary central incisor was prepared with $1.0 \mathrm{~mm}$ axial and $1.5 \mathrm{~mm}$ incisal reduction. Refractory dies were prepared and crowns were fabricated using the manufacturers recommendations. Six specimens of each system were placed inside a beaker in a furnace at $90^{\circ} \mathrm{C}$. After $15 \mathrm{~min}$ heat soak, ice water was poured into the beaker through a funnel. The samples were dried in air, reheated, and inspected for crazing using light microscopy. If crazing was observed, this would constitute a failure at a temperature difference $(\Delta \mathrm{T})$ of $90^{\circ} \mathrm{C}$. If no failure occurred, the test was repeated at increasing temperature increments of $10^{\circ} \mathrm{C}$ until failure. The crazing resistance of each system, expressed as the mean $\Delta \mathrm{T}$, was: $>200$ (Hi-Ceram $\left.{ }^{(\mathbb{B}}\right), \quad 163 \pm 14\left(\right.$ In-Ceram $\left.{ }^{(B)}\right), \quad 152 \pm 19$ (Dicor $^{\mathrm{TM}} /$ Vitadur $^{\circledR} \mathrm{N}$ ), $143 \pm 5$ (magnesia core/Vita $\mathrm{VMK}^{\circledR} 68$ ), $122 \pm 21$ (magnesia core/Silhouette ${ }^{\mathrm{TM}}$ ), and $118 \pm 10$ (magnesia core/Ceramco ${ }^{\circledR}$ II) ${ }^{\circ} \mathrm{C}$. All systems tested resisted crazing due to quenching in ice cold water from $100^{\circ} \mathrm{C}$. Systems with lower coefficients of expansion showed significantly greater resistance to thermal shock using ANOVA. (C) 1994 John Wiley \& Sons, Inc.

\section{INTRODUCTION}

The increased demand for esthetic dentistry in recent years has resulted in a variety of all-ceramic crown systems available for use by the dentist and dental technician. Some of these all-ceramic systems are actually a composite of two types of ceramic materials. Initially, a core layer consisting of a high strength ceramic material, either aluminous oxide, magnesium oxide, or glass, is fabricated which provides strength to the restoration. Secondly a feldspathic porcelain is fired directly onto the core to provide final contour and esthetics.

Several factors can influence the success of core reinforced all-ceramic crowns including, but not limited to, crown design, defects or flaws in the structure, processing techniques, and thermally induced residual stresses. These stresses are the result of differences in the coefficients of thermal expansion of the core and veneer porcelains, which must be similar to

*To whom correspondence should be addressed. prevent formation of stresses during the firing cycles that may subsequently craze the porcelain. ${ }^{1}$

In an ideal system, the core and body porcelains would match over the entire temperature range that would be encountered during a firing cycle used by dental technicians. However, this is difficult to achieve due to phase changes that occur in dental ceramics which result in nonlinear thermal expansion and contraction. Differences in the thermal expansion and contraction between the core and veneer porcelains could produce transient or residual tensile stresses in the porcelains. Transient stresses are created as the core and veneer porcelains cool at different rates from the glass transition temperature to room temperature, ${ }^{2}$ while residual stresses remain due to differences in the coefficients of thermal expansion (Fig. 1). Other terms used to describe the glass transition temperature $\left(\mathrm{T}_{\mathrm{g}}\right)$ are the Littleton softening point, ${ }^{3}$ the porcelain softening temperature, ${ }^{4}$ the deformation temperature, or the sag point. Although a common definition of the softening point is the temperature which produces a viscosity of $10^{7.6}$ poise, $, 3,6$ 
different $\mathrm{T}_{\mathrm{g}}$ values will be determined experimentally depending on the measurement technique used. ${ }^{6}$ The glass transition temperature is not an exact temperature but a temperature range since the transition from liquid to glassy behavior occurs over a range of temperatures. ${ }^{7}$

Residual stresses may be high enough to result in cracking or delamination of the porcelain upon cooling to room temperature after a firing cycle. It is generally believed that some residual stresses, such as those that place the porcelain in slight compression and help to strengthen it, would be beneficial. However, if these stresses are high they may produce microcracks that could propagate at a later time to produce failure.

Additional transient stresses may be produced from thermal shock to form cracks where initial stresses were not sufficient to cause porcelain fracture. Occlusal forces during mastication or sudden temperature change in an oral environment could provide additional stresses that might cause failure. ${ }^{8}$

Data from dilatometric measurements may be used to predict thermal compatibility of core reinforced all-ceramic crown systems. In addition, a practical method of testing the compatibility of porcelain for crown shaped specimens fabricated according to manufacturers' recommendations is to use a thermal shock test described by Anusavice et al. ${ }^{9}$ Thermal shock testing has shown a positive relationship with dilatometric data ${ }^{10}$ and the compatibility index described by Fairhurst et al. ${ }^{11}$ The purpose of this study was to use thermal shock testing to evaluate the crack resistance of six all-ceramic crown systems which have coefficients of thermal expansion ranging from $7-15.3 \times 10^{-6} /{ }^{\circ} \mathrm{C}$.

\section{MATERIALS AND METHODS}

The all-ceramic crown systems used in this study were Vita In-Ceram ${ }^{\circledR}$ (Vident, Baldwin Park, CA), Vita Hi-Ceram ${ }^{\circledR}$ (Vident), Dicor ${ }^{\mathrm{TM}}$ (Dentsply International Inc., York, PA) veneered with Vitadur ${ }^{\circledR} \mathrm{N}$ (Vident), and magnesia core material veneered with Vita VMK ${ }^{\circledR}$ 68 (Vident), Silhouette ${ }^{\mathrm{TM}}$ (Leach \& Dillon, Mansfield, $\mathrm{MA}$ ) or Ceramco $^{\circledR}$ II porcelains (Ceramco Inc., Burlington, NJ).

An ivorine maxillary central incisor (Columbia Dentoform, New York, NY) was prepared with $1.0 \mathrm{~mm}$ axial and $1.5 \mathrm{~mm}$ incisal reduction. A $90^{\circ}$ shoulder preparation with a rounded internal line angle was used as a master die for all samples. Thirtysix impressions of the master die were taken using a polyvinylsiloxane impression material (Reprosil ${ }^{\circledR}$ Light Body, L. D. Caulk Co., Milford, DE) which were then allowed to cure for $24 \mathrm{~h}$ before pouring in die stone or refractory die material.

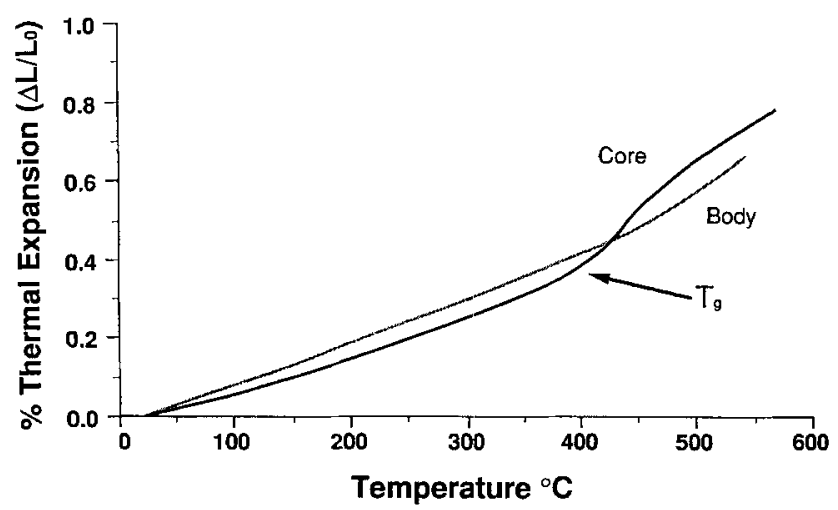

Figure 1. Typical thermal expansion curves for core and body porcelains in an all-ceramic crown system. Residual stresses are formed when the system is cooled below the measured glass transition temperature $\left(\mathrm{T}_{\mathrm{g}}\right)$.

All refractory die materials used in this study were mixed and degassed according to the manufacturers' recommendations. The Vita Hi-Ceram ${ }^{\circledR}$ cores were fabricated using Hi-Ceram ${ }^{\circledR}$ refractory die material with $\mathrm{Hi}$-Ceram ${ }^{\circledR}$ core porcelain fired directly on the refractory die. The Vita In-Ceram ${ }^{\circledR}$ cores were processed by a manufacturer's authorized commercial dental laboratory according to specifications. Both the InCeram $^{\circledR}$ and Hi-Ceram ${ }^{\circledR}$ were veneered with a $1.0 \mathrm{~mm}$ layer of Vitadur ${ }^{\circledast} \mathrm{N}$ dentine and enamel porcelains (see Table I for firing cycles).

Six impressions were poured in type IV stone (Die Keen $^{\circledR}$, Modern Materials, South Bend, IN) which provided dies to wax $1.0 \mathrm{~mm}$ thick copings to be cast in Dicor ${ }^{\mathrm{TM}}$ glass. After casting, the copings were cerammed, fitted to their respective master die, and dressed down to a thickness of $0.5 \mathrm{~mm}$ to allow room for application of Vitadur ${ }^{(i)} \mathrm{N}$ porcelain.

For the magnesia core crowns, 18 impressions were poured with Ceramco ${ }^{\circledR}$ refractory die material. Eighteen magnesia core crowns were fired to a thickness of $0.5 \mathrm{~mm}$ and fitted to their respective master dies. Three groups of six cores each were veneered with opaque and body porcelains using Silhouette ${ }^{\mathrm{TM}}$, Ceramco ${ }^{\circledR} \mathrm{II}$, or Vita VMK ${ }^{\circledR} 68$ porcelains. The opaque layer was approximately $0.3 \mathrm{~mm}$ thick and the body layer about $1.0 \mathrm{~mm}$. All crowns were fabricated to duplicate the size and shape of a maxillary central incisor to simulate the clinical application of these porcelains.

Six specimens of each system were placed inside a $100 \mathrm{~mL}$ beaker in an oven (Boekel Industries, Inc., Philadelphia, PA) preheated to $90^{\circ} \mathrm{C}$. The temperature was monitored using a thermometer placed inside the beaker next to the samples. After a 15 min heat soak to allow the samples to reach temperature equilibrium, water at $0^{\circ} \mathrm{C}$ was poured into the beaker via a funnel placed through a hole in the ceiling of the oven.

The samples were removed from the furnace, dried in air, then reheated to $90^{\circ} \mathrm{C}$ for $15 \mathrm{~min}$ and allowed to 
TABLE I

Firing Cycles for the Porcelains Tested

\begin{tabular}{|c|c|c|c|c|c|}
\hline Porcelain System & $\begin{array}{c}\text { Initial Temperature } \\
\left({ }^{\circ} \mathrm{C}\right)\end{array}$ & $\begin{array}{l}\text { Heat Rate } \\
\left({ }^{\circ} \mathrm{C} / \mathrm{min}\right)\end{array}$ & $\begin{array}{c}\text { Vacuum Release } \\
\left({ }^{\circ} \mathrm{C}\right)\end{array}$ & $\begin{array}{c}\text { Maximum Temperature } \\
\left({ }^{\circ} \mathrm{C}\right)\end{array}$ & Holding Time \\
\hline \multicolumn{6}{|l|}{ Core porcelains/glass } \\
\hline Hi-Ceram ${ }^{\circledR}$ & 650 & 30 & 960 & 960 & $1 \min$ \\
\hline Magnesia $^{\mathbb{B}}$ & 590 & 10 & 1120 & 1120 & $5 \mathrm{~min}$ \\
\hline \multicolumn{6}{|l|}{ Dicor $^{T M *}$} \\
\hline \multicolumn{6}{|l|}{ In-Ceram ${ }^{\circledast \dagger}$} \\
\hline \multicolumn{6}{|l|}{ Opaque porcelains } \\
\hline Ceramco $^{\circledR}$ II & 650 & 38 & 930 & 1000 & $30 \mathrm{sec}$ \\
\hline Silhouette ${ }^{\mathrm{TM}}$ & 540 & 55 & 970 & 970 & $10 \mathrm{sec}$ \\
\hline Vita VMK ${ }^{\circledR} 68$ & 800 & 32 & 960 & 960 & $10 \mathrm{sec}$ \\
\hline \multicolumn{6}{|l|}{ Body porcelains } \\
\hline Ceramco $^{\circledR}$ II & 650 & 38 & 930 & 970 & $30 \mathrm{sec}$ \\
\hline Silhouette $\mathrm{TM}^{\mathrm{TM}}$ & 540 & 55 & 960 & 960 & $10 \mathrm{sec}$ \\
\hline Vita $\mathrm{VMK}^{\circledR} 68$ & 750 & 32 & 960 & 960 & $10 \mathrm{sec}$ \\
\hline Vitadur $^{\circledR} \mathrm{N}$ & 590 & 58 & 1170 & 1170 & $3 \min$ \\
\hline
\end{tabular}

${ }^{*}$ See Dicor ${ }^{\mathrm{TM}}$ Laboratory Technique Manual, Dentsply International Inc., York, PA, 1984.

tSee Vita In-Ceram ${ }^{\circledast}$ Instruction Manual, Vita Zahnfabrik, H. Rauter GmbH \& Co. KG, D-7880 Bad Säckingen, Germany, 1990.

cool to room temperature. The crowns were inspected for crazing using light microscopy at $10 \times$ magnification (Stereomicroscope SV8, Carl Zeiss, Oberkocken, Germany) with fiber optic illumination.

If crazing was observed, this would constitute a failure at $\Delta \mathrm{T}=90^{\circ} \mathrm{C}$. If no failure was observed, the test was repeated at increasing temperature increments of $10^{\circ} \mathrm{C}$ until failure. A one-way analysis of variance was performed on the 36 samples to determine the effect of brand on thermal shock resistance, $\Delta \mathrm{T}$. Pairwise comparisons were run with simultaneous confidence intervals.

The samples for dilatometric measurement were compressed in a metal mold to provide rectangular bars $6 \times 6 \times 51 \mathrm{~mm}$. The bars were fired according to the schedule recommended by the manufacturers of the various porcelains. The thermal dilatometric analyzer (Model TDA-H1-MP6, Harrop Laboratories, Columbus, $\mathrm{OH}$ ) was calibrated on the cooling curve using an alumina standard. The coefficient of thermal expansion values were determined on the second heating-cooling cycle between $25^{\circ} \mathrm{C}$ and $500^{\circ} \mathrm{C}$ with a heating and cooling rate of $4^{\circ} \mathrm{C} / \mathrm{min}$.

\section{RESULTS}

For each ceramic system the mean $\Delta \mathrm{T}$ value, standard deviation and $\Delta \mathrm{T}$ range are shown in Table II. The data are based upon the results from the 36 samples tested, six for each system. The $\Delta T$ value represents the temperature difference required to produce a failure in the ceramic. Coefficients of thermal expansion are reported in Table III. A comparison of the types of fracture observed for the various ceramic systems is given in Table IV.
A one-way ANOVA showed there was a significant effect of ceramic systems on thermal shock resistance, $\Delta \mathrm{T}(P<.0001)$. The magnesia core systems had $\Delta \mathrm{T}$ values ranging from $90-150^{\circ} \mathrm{C}$, with the magnesia core/Ceramco $^{\circledR}$ II, magnesia core/Silhouette ${ }^{\mathrm{TM}}$, and magnesia core/Vita VMK ${ }^{\circledR} 68$ systems having mean $\Delta \mathrm{T}$ values of $118^{\circ} \mathrm{C}, 122^{\circ} \mathrm{C}$, and $143^{\circ} \mathrm{C}$, respectively. They were not statistically different from one another using the Scheffé $\mathrm{F}$ test at the $95 \%$ confidence level.

The Dicor ${ }^{\mathrm{TM}} /$ Vitadur $^{\circledR} \mathrm{N}$ system had a mean $\Delta \mathrm{T}$ value of $152^{\circ} \mathrm{C}$ with a failure range of $120-170^{\circ} \mathrm{C}$. For the In-Ceram ${ }^{\circledR}$ system, the mean $\Delta \mathrm{T}$ value was $163^{\circ} \mathrm{C}$ and cracking resulted in a $\Delta \mathrm{T}$ range of $150-180^{\circ} \mathrm{C}$. The Hi-Ceram ${ }^{\circledR}$ had the highest thermal shock resistance of the systems tested with no failures at temperatures up to $200^{\circ} \mathrm{C}$.

The mean $\Delta \mathrm{T}$ values for the Dicor ${ }^{\mathrm{TM}} /$ Vitadur $^{\circledR} \mathrm{N}$ and In-Ceram ${ }^{\circledR}$ systems were statistically higher than the mean $\Delta \mathrm{T}$ values for the magnesia core/ Ceramco ${ }^{\circledR}$ II and magnesia core/Silhouette ${ }^{\mathrm{TM}}$ systems. The mean $\Delta \mathrm{T}$ value for the magnesia core/ Vita VMK ${ }^{\circledR} 68$ system was not significantly different from the mean $\Delta \mathrm{T}$ values of the other systems except for the mean $\Delta T$ value of the Hi-Ceram ${ }^{\circledR}$ system, which was significantly higher than the mean $\Delta \mathrm{T}$ values of all other systems tested.

\section{DISCUSSION}

The thermal shock test can serve as a practical method for testing the thermal compatibility of allceramic crown systems. It can be used to identify systems where residual stresses are not of a sufficient magnitude to cause failure upon completion of the initial firing cycle, but which could cause failure at a 
TABLE II

$\Delta T$ Values that Resulted in Failure

\begin{tabular}{|c|c|c|c|}
\hline Porcelain & $\mathrm{n}$ & Mean $\Delta \mathrm{T} \pm \mathrm{SD}\left({ }^{\circ} \mathrm{C}\right)$ & $\Delta \mathrm{T}$ Range $\left({ }^{\circ} \mathrm{C}\right)$ \\
\hline Magnesia Core/Ceramco ${ }^{\circledR}$ II & 6 & $118 \pm 10$ & $110-130$ \\
\hline Magnesia Core/Silhouette $\mathrm{T}^{\mathrm{TM}}$ & 6 & $122 \pm 21$ & $90-140$ \\
\hline Magnesia Core/Vita VMK ${ }^{\circledR} 68$ & 6 & $143 \pm 5$ & $140-150$ \\
\hline Dicor $^{\mathrm{TM}} /$ Vitadur $^{(\mathbb{B})} \mathrm{N}$ & 6 & $152 \pm 19$ & $120-170$ \\
\hline In-Ceram ${ }^{(1)}$ & 6 & $163 \pm 14$ & $150-180$ \\
\hline $\mathrm{Hi}-\mathrm{Ceram}^{\circledR}$ & 6 & $>200$ & $>200$ \\
\hline
\end{tabular}

Groups joined by vertical lines are not significantly different using Scheffé $\mathrm{F}$ test at the $95 \%$ confidence level.

later time when crowns are in service. ${ }^{12}$ However, it only measures the effect of thermal change on stresses, but not the effect of cyclic mechanical stresses. It should be noted that the thermal shock test does not correlate well with clinical failure because of the many factors involved in this complex system.

If a porcelain has a low coefficient of thermal expansion, the contraction upon cooling is small and the resulting residual stresses are low. This is indicated by the following equation ${ }^{3}$ :

$$
\Delta \mathrm{T}_{\mathrm{f}}=\frac{\sigma_{\mathrm{f}}(1-\mu)}{\alpha \mathrm{E}} \mathrm{S}
$$

where $\Delta T_{f}$ is temperature difference when fracture occurs, $\sigma_{\mathrm{f}}$ is the fracture stress, $\mu$ is Poisson's ratio, $\mathrm{E}$ is modulus of elasticity, $\alpha$ is linear coefficient of thermal expansion, and $S$ is a shape factor. This relationship applies when the quench is so rapid that the surface temperature reaches its final value before the average temperature changes. By this criterion of failure, a material with high fracture stress, low modulus of elasticity, and low thermal expansion coefficient will likely be resistant to thermal stress failure. $^{3}$ Therefore, porcelains with a low coefficient of thermal expansion tend to have high thermal shock resistance. The results in this study demonstrated this principle. The Hi-Ceram ${ }^{\circledR}$ and In-Ceram ${ }^{\circledR}$ systems had the highest shock resistance. Both are aluminabased systems, and therefore have low coefficients of thermal expansion. The Dicor ${ }^{\mathrm{TM}} /$ Vitadur $^{\circledR} \mathrm{N}$ system had a lower thermal shock resistance than the HiCeram $^{\circledR}$ or In-Ceram ${ }^{\circledR}$ systems. Again this could be due to the relatively low coefficients of thermal expansion of the Dicor ${ }^{\mathrm{TM}}$ cast glass and the Vitadur ${ }^{(B)}$ $\mathrm{N}$ porcelain (Table III). The magnesia core material has a higher coefficient of thermal expansion than do the three feldspathic porcelains tested (Cermaco ${ }^{\circledR}$ II, Vita VMK ${ }^{\circledR} 68$, and Silhouette ${ }^{\mathrm{TM}}$ ). However, these systems showed adequate thermal shock resistance since thermal shocks of $100^{\circ} \mathrm{C}$ and above would not be likely in vivo.

The stresses which arise from thermal shock are transient but can initiate failure if they place the surface in tension as would be the case for rapid cooling. If these surface stresses are sufficiently large
( $\Delta \mathrm{T}$ is large in the above equation) cracks can be initiated on the surfaces of brittle materials. For the system investigated here, these surface cracks would be expected to occur in the body porcelain because this material is weaker than the core material and because the thermal shock to the outer surface of a crown would be greater than for the inner surface where the external surface of the core material is located. These surface cracks will propagate into the bulk of the material and interact with internal residual stresses. The nature of these residual stresses will determine the path followed by the thermal shock induced surface crack as it propagates inward.

While a crown is a complicated system, some general comments can be made about residual stresses. When the coefficient of thermal expansion of the core is greater than that of the opaque/body porcelain, then the body porcelain will be in radial tension while the hoop stresses will be compressive following cooling after firing. These residual stresses will be greatest at the opaque/core interface. As a surface crack propagates inward, it will be deflected in the direction of higher tensile stress, which in this case would be along a surface tangential to the opaque/core interface. This type of crack can often be seen to deflect, running parallel to the core due to the tensile stresses present. This type of fracture usually appears as a curved line or a half-moon shape that runs in a mesial/distal direction (Fig. 2). For complete

TABLE III

Typical Values of Coefficient of Thermal Expansion for Various Ceramics

\begin{tabular}{lc}
\hline \multicolumn{1}{c}{ Material } & $\mathrm{CE} \times 10^{-6}\left(\right.$ per $\left.^{\circ} \mathrm{C}\right)$ \\
\hline Dicor $^{\mathrm{TM} *}$ & 7 \\
In-Ceram $^{\circledR}$ & 6.2 \\
Hi-Ceram $^{\circledR}$ & 8.0 \\
Magnesia Core Frit \#101691 $^{\circledR}$ & 15.3 \\
Vitadur $^{\circledR} \mathrm{N}^{\dagger}$ & 6.7 \\
Ceramco $^{\circledR} \mathrm{II}$ & 13.4 \\
Silhouette $^{\mathrm{TM}}$ & 14.0 \\
Vita VMK $^{\circledR} 68^{+}$ & 12.7
\end{tabular}

* Reference 14.

${ }^{+}$Vident, Baldwin Park, CA. 
TABLE IV

Description of Fractures for Core Reinforced All-Ceramic Crowns

\begin{tabular}{|c|c|c|c|}
\hline \multirow[b]{2}{*}{ System } & \multicolumn{2}{|r|}{ Type of Fracture } & \multirow[b]{2}{*}{ Branched } \\
\hline & Horizontal/Tangential & Vertical/Radial & \\
\hline Magnesia Core/Vita VMK ${ }^{\circledast} 68$ & 6 & 0 & 0 \\
\hline Magnesia Core $/$ Ceramco $^{\circledR} \mathrm{II}$ & 4 & 2 & 0 \\
\hline Magnesia Core/Silhouette ${ }^{\mathrm{TM}}$ & 0 & 5 & 1 \\
\hline Dicor $^{\mathrm{TM}} /$ Vitadur $^{(\mathbb{B}} \mathrm{N}$ & 0 & 2 & 4 \\
\hline In-Ceram $^{\circledast} /$ Vitadur $^{\circledR} \mathrm{N}$ & 3 & 0 & 3 \\
\hline Hi-Ceram $^{\circledast} /$ Vitadur $^{\circledast} \mathrm{N}$ & & & No failures observed at $\Delta \mathrm{T}=200^{\circ} \mathrm{C}$ \\
\hline
\end{tabular}

failure chips of porcelain and opaque would break off from the core material.

When the coefficient of thermal expansion of the core is less than that of the opaque/body porcelain, the hoop stresses in the opaque/body porcelain will be tensile while the radial stress will be compressive. In this case the thermal shock induced surface crack will be driven radially inward by the residual tensile hoop stresses. The fractures appeared as a vertical line running in the occlusal/gingival direction (Fig. 3). These fractures would likely be arrested in the

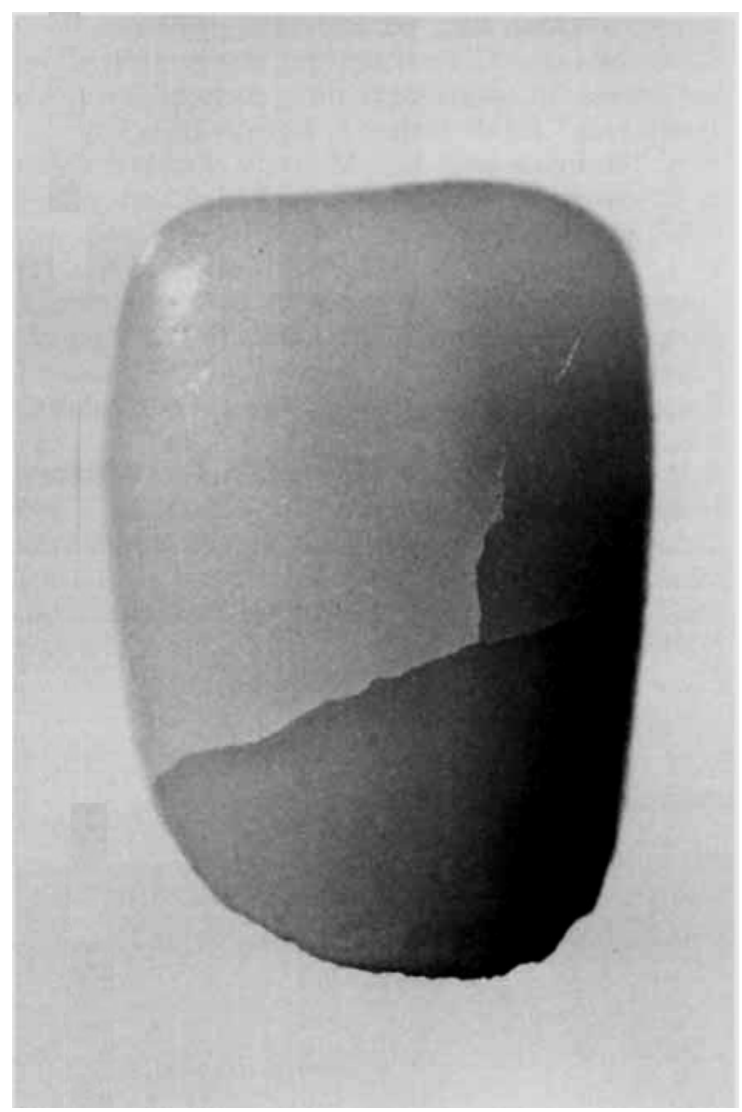

Figure 2. A core reinforced all-ceramic crown with cracks visible after thermal shock testing. This type of fracture is an example of cracks resulting from tangential stresses. The temperature difference when fracture occurred was $110^{\circ} \mathrm{C}$. stronger core material where the hoop stresses would be compressive.

By rotating the crown under illumination the direction of the cracks can be seen and also if the crack penetrates the core or turns to run tangentially to the core. This will help to identify if the cracks are the result of radial tensile (vertical crack) or radial compressive (horizontal crack) stresses. Identifying the type of crack will also help to determine what type of thermal expansion mismatches may exist between the core and body porcelains.

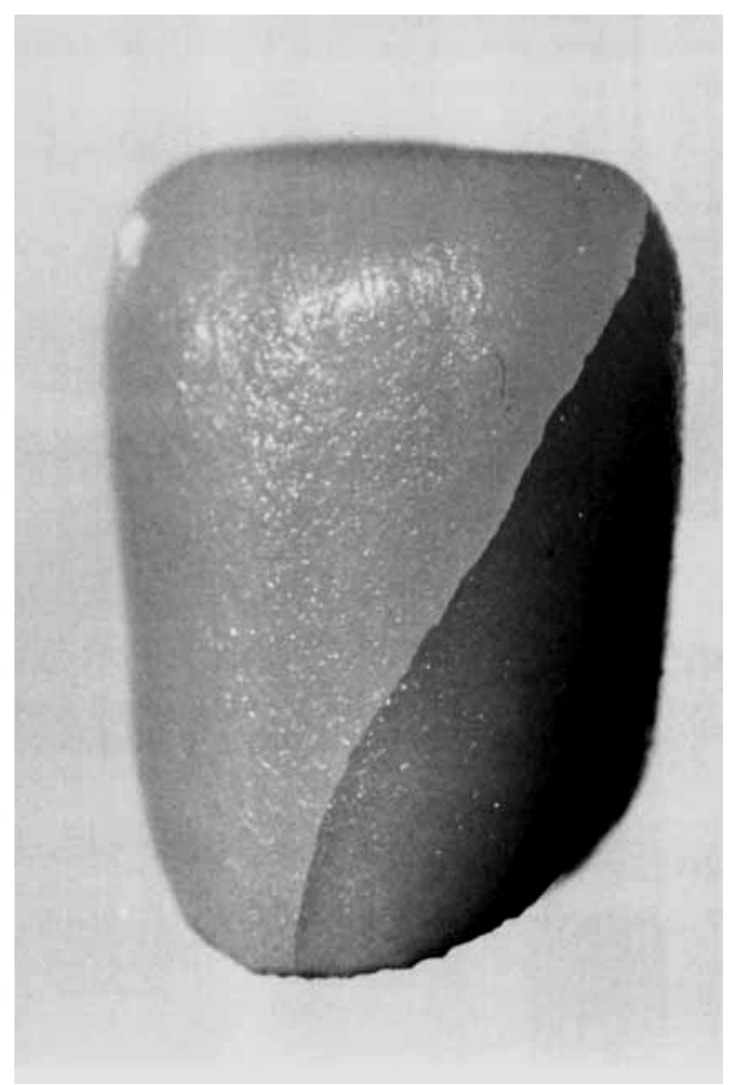

Figure 3. A core reinforced all-ceramic crown with cracks visible after thermal shock testing. This type of fracture is an example of cracks resulting from radial stresses and will usually penetrate into the core. The temperature difference when fracture occurred was $100^{\circ} \mathrm{C}$. 
Several factors can influence the thermal shock resistance of all-ceramic systems. Obviously, a significant difference in thermal expansion between the two porcelains would produce residual stresses. The thermal conductivity and interfacial bond strength between the layers of porcelain also affect thermal shock resistance. As the thermal conductivity increases, the shock resistance will decrease. ${ }^{13}$

The elastic moduli of the porcelains as well as the dimensions of the restoration also play a role. As the thickness of the porcelain varies from one layer to another, the stiffness changes and the residual stresses are altered. For this reason, the incisor crown shape was used for all samples in this study to insure consistent geometry.

\section{CONCLUSIONS}

A thermal shock test was used to evaluate the crack resistance of six composite all-ceramic crown systems. The test results agree with anticipated results that alumina core and body porcelain systems with lower coefficients of thermal expansion had higher thermal shock resistances than magnesia-based systems with body porcelains having higher coefficients of thermal expansion. All the systems tested had adequate thermal shock resistance for clinical use.

The authors thank Dr. Stephen T. Rasmussen for many helpful suggestions, Carole L. Groh for her valuable assistance in preparation of the manuscript, and Vident, Baldwin Park, CA, for their donation of materials to this study.

This investigation was supported by Grants 1 P50 DE09296 and G5R01DE05423 from the National Institute of Dental Research, National Institutes of Health, Bethesda, MD 20892.

\section{References}

1. K. Asaoka and J. A. Tesk, "Transient and residual stress in a porcelain-metal strip," J. Dent. Res., 69, 463-469 (1990).
2. K. J. Anusavice, P.H. DeHoff, S.W. Twiggs, and P. C. Lockwood, "Thermal shock resistance of porcelain disks," J. Dent. Res., 62, 1082-1085 (1983).

3. W.D. Kingery, H.K. Bowen, and D.R. Uhlmann, Introduction to Ceramics, 2nd ed., New York, John Wiley and Sons, Inc., 1976.

4. R. L. Bertolotti and H. Fukui, "Measurement of softening temperatures in dental bake-on porcelains," J. Dent. Res., 61, 480-483 (1982).

5. D.W. Richerson, Modern Ceramic Engineering, New York, Marcel Dekker, Inc., 1982.

6. P.H. DeHoff and K.J. Anusavice, "An analytical model to predict the effects of heating rate and applied load on glass transition temperatures of dental porcelain," J. Dent. Res., 65, 643-647 (1986).

7. O.S. Narayanaswamy, "A model of structural relaxation in glass," J. Am. Ceram. Soc., 54, 491-498 (1971).

8. M. Bagby, S. J. Marshall, and G.W. Marshall, "Metal ceramic compatibility: a review of the literature," J. Prosthet. Dent., 63, 21-25 (1990).

9. K.J. Anusavice, R.D. Ringle, P.K. Morse, C.W. Fairhurst, and G.E. King, "A thermal shock test for porcelain-metal systems," J. Dent. Res., 60, 1686-1691 (1981).

10. K. J. Anusavice, S. W. Twiggs, P.H. DeHoff, and C.W. Fairhurst, "Correlation of thermal shock resistance with thermal compatibility data for porcelainmetal systems," J. Dent. Res., 61, 419-422 (1982).

11. C.W. Fairhurst, K.J. Anusavice, R.D. Ringle, and S. W. Twiggs, "Porcelain-metal thermal compatibility," J. Dent. Res., 60, 815-819 (1981).

12. K. Asaoka and N. Kuwayama, "Estimation on residual stress in porcelain/alloy system by thermal shock test," Dent. Mater. J., 5, 145-157 (1986).

13. A.S. Tetelman and A.J. McEvily, Fracture of Structural Materials, New York, John Wiley and Sons, Inc., 1967, pp. 598-608.

14. W.J. O'Brien, E.R. McPhee, and L.W. Seluk, "Strength of a high-expansion core porcelain," in Perspectives in Dental Ceramics: Proceedings of the Fourth International Symposium on Ceramics, J.D. Preston (ed.), Chicago, Quintessence Publishing Co, Inc., 1988, pp. 167-174.

15. R.P. Whitlock, J.A. Tesk, G.E. O. Widera, A. Holmes, and E. E. Perry, "Consideration of some factors influencing compatibility of dental porcelains and alloys. Part I; Thermo-physical properties," in Proceedings of the 4th International Precious Metals Conference, Willowdale, Ontario, Pergamon Canada, 1981, pp. 273-282.

Received April 1, 1993

Accepted August 26, 1993 